Guest Editorial, part of a Special Feature on Practicing Panarchy: Assessing Legal Flexibility, Ecological Resilience, and Adaptive Governance in U.S. Regional Water Systems Experiencing Climate Change

\title{
Introduction to the Special Feature Practicing Panarchy: Assessing legal flexibility, ecological resilience, and adaptive governance in regional water systems experiencing rapid environmental change
}

\author{
Barbara A. Cosens ${ }^{1}$, Lance Gunderson ${ }^{2}$ and Brian C. Chaffin ${ }^{3}$
}

\begin{abstract}
This special feature presents articles on the cross-scale interactions among law, ecosystem dynamics, and governance to address the adaptive capacity of six watersheds in the United States as they respond to rapid environmental change. We build on work that assesses resilience and transformation in riverine and wetland social-ecological systems across the United States at a variety of scales, levels of development, and degrees of degradation, focusing specifically on the Anacostia River, Central Platte River, Klamath River, Columbia River, Middle Rio Grand River, and the Everglades wetlands. All of these cases involve complex institutional systems, histories involving ecological and social regime shifts, and are operated under similar constitutional and legal frameworks for the division of authority among federal, state, local, and where applicable, tribal governments. We focus on the legal dimensions of watershed governance that directly relate to ecological resilience and transformability of the social-ecological systems. We synthesize the results of these assessments to advance our understanding of the role of law and governance as a trigger, facilitator, or barrier to adaptation and transformation in the face of rapid environmental change, including shifting climate. This introductory article defines terminology and theoretical concepts to present a bridging framework between U.S. law and ecological resilience that can be used by the remaining articles in this special issue.
\end{abstract}

Key Words: adaptive governance; climate change; environmental law; resilience; water law; water management

\section{INTRODUCTION}

Human engineered control of water dates as early as $1200 \mathrm{BC}$ in North America, but has accelerated at an unprecedented rate and scale over the past century. From the arid southwestern region of the continent to the relatively water rich east, humans have sought to control surface waters and tap vast groundwater resources. In the ultimate effort to modify basic ecosystem functions for the service of humans, dams have been built in the mighty snowmelt driven rivers of western North America, the Columbia, the Colorado, and the Missouri, to control floodwaters, produce electricity, and divert water resources for irrigation and human consumption. This substantial investment in infrastructure required collective action and government subsidy. Today that infrastructure is aging and it is not clear whether the political will to modernize it exists. We are just beginning to realize the full extent of the costs to ecosystem services. Loss of biodiversity, as indicated by the large number of endangered and threatened species and cultures, and loss of ecosystem services provided by wetlands, floodplains and connected river and riparian corridor continue, but in ways that are difficult to quantify. Both the planned and inadvertent ecological changes associated with the development of water resources have led to unforeseen system shifts characterized as the erosion of ecological resilience (Holling 1973, Gunderson and Pritchard 2002). In addition, marginalized populations did not share equally in the benefits of 20th century development adversely affecting overall social resilience.

As changes to the water resources of North America have occurred, the ways in which humans have valued and governed these systems have also changed (Gunderson et al. 1995). Once viewed merely as a resource to be controlled to serve humans, water is now seen to supply a wide variety of ecosystem goods and services many of which society now values in their unaltered state. The rise of the social objective of sustainability extended the time horizon for social goals and outcomes by considering the needs of future generations (Brundtland Commission 1987). During this period of development and changing values, the human dimensions (including institutions made up of laws, rules, social norms, and patterns of management) have increased in complexity. Attempting to understand such patterns of complexity has led to integrative scholarship that directs attention to linking the social and ecological components of these systems (Berkes et al. 2002, Delmas and Young 2009).

This special feature is a result of a three-year synthesis pursuit, called the Adaptive Water Governance (AWG) project of the U. S. National Socio-Environmental Synthesis Center (SESYNC) that was funded by the U.S. National Science Foundation. The AWG Project explored the role of law in achieving water governance that is capable of facilitating management, adaptation and transformation in the face of climate change. Key questions that were addressed in the project include the following:

- Could ecological resilience and adaptive capacity of regional scale water systems to changing climate be qualitatively assessed to a useful degree?

- What is the role of environmental governance in developing the adaptive capacity of these systems to respond to climate change?

- What legal and institutional components contribute to adaptive governance?

- What is the role of law in preventing, triggering, and facilitating adaptive governance?

${ }^{1}$ University of Idaho College of Law, Moscow, ID, USA, ${ }^{2}$ Department of Environmental Sciences, Emory University, Atlanta, GA, USA, ${ }^{3}$ W.A.

Franke College of Forestry \& Conservation, University of Montana, Missoula, MT, USA 
Fig. 1. Location of regional scale, social-ecological water systems in the United States.

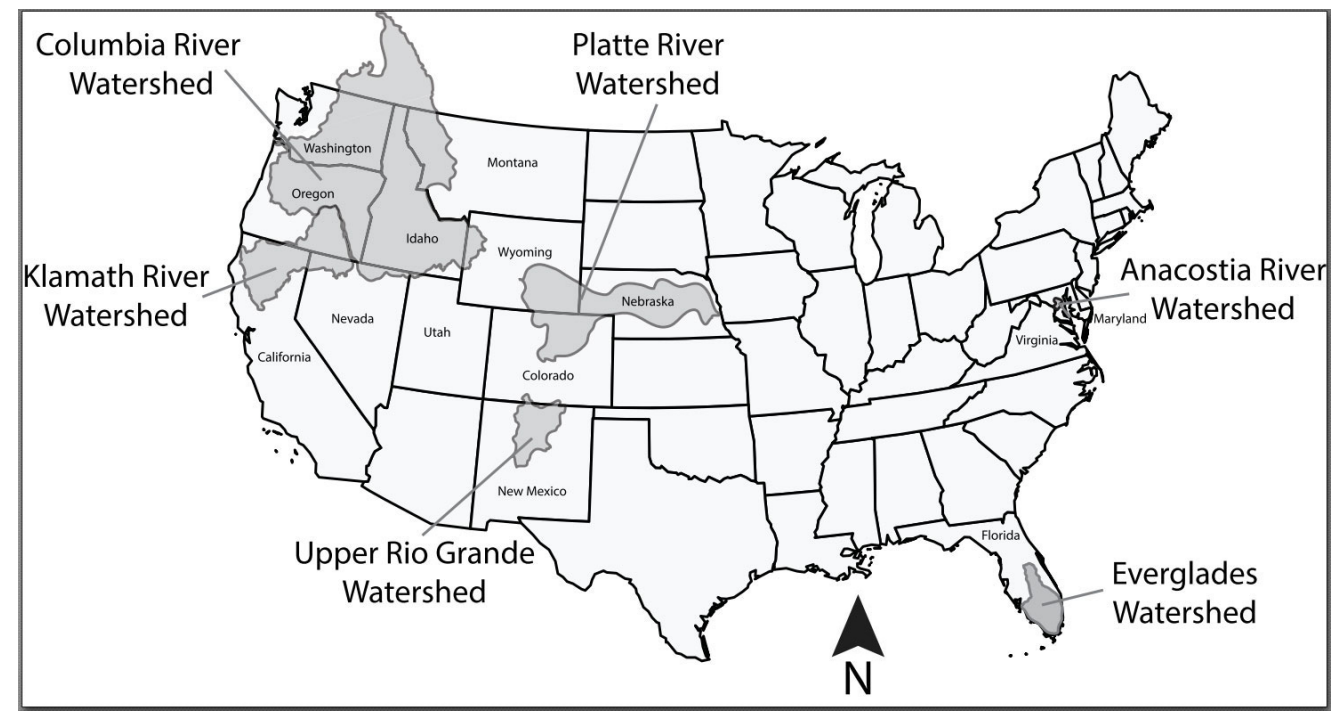

We attempted to answer these questions by bringing together interdisciplinary teams of legal, biophysical, and social science scholars who are embedded in and have knowledge of six regional social-ecological water systems undergoing changing climate (Fig. 1). Case studies from six North American water basinsAnacostia River (Arnold et al. 2014), Columbia River (Cosens and Fremier 2014), Klamath River (Chaffin et al. 2014a), Middle Rio Grande River (Benson et al. 2014), Platte River (Birge et al. 2014), and the Everglades (Gunderson et al. 2014)-were published in the "Natural Resources \& Environmental Law Edition" of the Idaho Law Review (2014), and are summarized by Gunderson et al. (2017) in this special feature. We build on those case studies in this special feature. Since publication of the case studies, associated concepts on the role of law have been applied to the Lake Eyre and Great Artesian basins in Australia and the lessons from this additional non-U.S. perspective (Cosens 2015), are included in some of the articles in this special feature. We begin with a common understanding of terms, then briefly introduce the articles resulting from the application of comparative and synthesis approaches to the basin assessments.

\section{ECOLOGICAL RESILIENCE AND ADAPTIVE ENVIRONMENTAL GOVERNANCE}

Applied ecologists (Holling 1973, 1978) recognized the uncertain, surprising and nonlinear behavior across a range of resource systems and proposed adaptive management (Holling 1978, Walters 1986) as an approach to confront deep uncertainties inherent in resource systems. A few of the regional water management systems in the U.S., such as the Columbia River (Lee 1993), Colorado River (Hughes et al. 2007), and the Everglades (LoSchiavo et al. 2013) have attempted to adopt and implement adaptive management. However, many efforts to implement adaptive management have run into barriers with respect to legal and governance issues (Dietzet al. 2003, Brunner et al. 2005, Folke et al. 2005, Gunderson and Light 2006). Governance approaches that appear to support management in the face of uncertainty have been identified and referred to in the literature under terms ranging from new governance to collaborative governance/ comanagement and adaptive governance, and were observed to be emergent, i.e., self-organizing, phenomena (Dietz et al. 2003, Karkkainen 2004, Brunner et al. 2005, Folke et al. 2005, Gunderson and Light 2006, Chaffin et al. 2014b). We use the phrase adaptive governance as an umbrella term to capture emergent, collaborative, and learning-based types of environmental governance (Chaffin et al. 2014b).

Governance of natural resources addresses issues of access, use, protection, and management of common pool resources including water (Delmas and Young 2009). Historically in North America we have relied on the mechanisms of markets, i.e., through private property rights, and government regulation to curb overexploitation (Hardin 1968). Markets are highly adaptive in response to change, but they also exhibit negative environmental externalities. Governmental regulation in the environmental area has grown dramatically since the 1960s to address these issues (Lemos and Agrawal 2006, Lyon 2009).

There is a growing recognition that both in the absence of regulation, and within highly regulated systems, self-organization of communities dependent on common pool resources is common and provides a path forward beyond the constraints of markets and regulation alone. Ostrom (2009) won a Nobel Prize for her work toward understanding why some social groups self-organize to regulate and manage natural resources in ways that sustain the resources and avoid overuse and other ecological consequences. Effectively, Ostrom's work added a third approach to the study of water and natural resource management, joining the principles of property and governmental regulation (Hardin 1968) that have dominated the development of water and related environmental law. The importance of self-organization as a third prong of management of common pool resources lies in its twofold ability to be more nimble and adaptive than government regulation while addressing the issues that arise in market failure. In reality, all three mechanisms, markets, regulation, and self-organization may be employed simultaneously in response to the need for 
environmental governance. Learning when and in what combination to support each mechanism is one of the keys to adaptive environmental governance (Cosens 2016).

\section{Defining terms: an interdisciplinary exercise}

Our effort to bridge ecological resilience and adaptive environmental governance through cross-disciplinary research required that the participants reach agreement on the definitions of terms (Repko 2011). As such, we do not seek to put new definitions forward or to resolve disciplinary disputes over differing opinions on a particular term or phrase. Instead, we simply seek to communicate the definitions agreed upon and used throughout this special feature. Because of our understanding of the complex, surprising, and turbulent history of water resource systems, we ground our inventory of bridging terminology in three phases: (a) resilience thinking, (b) environmental governance and (c) adaptive governance.

\section{Resilience thinking}

Resilience thinking is a family of concepts used to describe the abrupt and surprising behaviors observed in complex systems and documented in many ecosystems (Gunderson and Pritchard 2002). Resilience thinking posits that coupled social-ecological systems may organize in alternative, meta-stable regimes or states; it posits that a perturbation or disturbance may cause the system to cross a threshold into another configuration or regime; and that once a regime shift occurs, it may or may not return in structure and function (Holling 1973, Gunderson and Holling 2002, Walker et al. 2004, Walker and Salt 2006). Although the term was coined to refer to this entire phenomenon of systems, "resilience" is more often used to describe the degree to which the system avoids regime shift either because it is quite adaptable (latitude) or quite resistant to change (resistance; Walker et al. 2004). Because resilience is often discussed in terms of the system society seeks to maintain, the term resilience is often confused with the goal itself. Resilience as used in this issue is value neutral, and thus, is a property both of systems society values and those they do not value (Holling 1973, Gunderson and Holling 2002, Walker et al. 2004, Walker and Salt 2006). Nevertheless, society does make value judgments about alternative states. Indeed, much of adaptive governance is about contrasting and weighing alternative values of different ecological states. It is within governance that the desire for a particular alternative state is expressed; it is resilience, i.e. the system properties, that informs how to get there within a complex system.

Resilience thinking allows us to approach complex systems from the viewpoint of their ability to continue to provide key functions and maintain supporting structure in the face of change (Holling 1973, Gunderson and Holling 2002, Walker et al. 2004, Walker and Salt 2006). It provides a framework for environmental management of nonstationary systems by focusing attention on achieving societal goals without simplification of the processes that support ecosystem function, and in fact, by supporting those processes rather than a single stationary state, e.g., maximum sustainable yield (Walker and Salt 2006). It ties society's response to change in an ecological system to the complex feedbacks between the social and ecological system (Holling and Gunderson 2002), improving the prospects for achieving the goal of sustainability.
A related concept, panarchy, provides a dynamic cross-scale lens through which both social-ecological systems and their systems of governance can be viewed (Gunderson and Holling 2002). Panarchy describes the existence of systems in a nested, interconnected, hierarchy in various stages of growth, collapse, innovation, and reorganization. Thus, within a social-ecological system at the landscape scale, are multiple interconnected smaller scale systems down to the microscopic in the ecological realm and down to the individual in the societal realm. Panarchy expands the concept of resilience by recognizing that (a) resilience of a system declines as a system matures or develops; (b) larger (slower) and smaller (faster) scale processes interact and can both foster and erode resilience; and (c) cross scale interactions may play a role in transformations into new regimes in both ecological and social system configurations (Chaffin et al. 2016). These aspects of panarchy are also observed in our systems of governance (Chaffin and Gunderson 2016), and understanding the current trajectory of the system can aid in intentional adaptation and transformation (Gunderson et al. 2017).

\section{Environmental governance}

Environmental governance refers to the means through which collective goals related to society's interaction with natural systems are chosen, decisions are made, and action is taken to achieve the chosen goals (Rogers and Hall 2003, Delmas and Young 2009, U.N. System Task Team 2012). The term governance encompasses not only government, but the relationship between government and society, including the means through which private actors, markets, and interest-based networks influence policy decisions (Rogers and Hall 2003, Folke et al. 2005, Lemos and Agrawal 2006, Huitema et al. 2009).

\section{Adaptive governance}

Adaptive governance is simply environmental governance that allows emergence of collective action capable of facilitating adaptation to change and surprise as well as the capacity to itself evolve (Dietz et al. 2003, Folke et al. 2005, Chaffin et al. 2014b, Cosens et al. 2014, Green et al. 2015, Schultz et al. 2015). That adaptive governance is emergent is a key starting point for inquiry into the role of law. Law itself is intentional. The genius of Nobel Laureate Elinor Ostrom, who documented self-organization of communities around governance of natural resources (Ostrom 2009), was to demonstrate the fallacy of neoclassic economic theory, which assumes that self-interest renders communities incapable of collaboration to solve serious societal problems. Ostrom (1990) offered an alternative framework in which community-based common property institutions evolve to become capable of managing common pool resources as effectively as formal government regulation or the division of resources into privately held property (McGinnis and Ostrom 2014). It is this self-organizing behavior that characterizes emergent collaborative processes that we seek to understand in the AWG project. Yet in our highly developed North American water systems, that emergence must take place within a system of governmental management of the environment and regulation of those who use it. Our focus is on emergence of adaptive governance nested within and interacting with highly developed systems of government and how government, acting through law, might step aside and even facilitate this emergence. To understand the role of law, we must first understand this self-organizing behavior. 
Chaffin et al. (2014b), review the literature on adaptive governance, adaptive comanagement, and collaborative conservation to take a very broad view of adaptive governance as a "range of interactions between actors, networks, organizations, and institutions emerging in pursuit of a desired state for social-ecological systems." For purposes of understanding the role of law, we are particularly drawn to those works that have recognized emergence of adaptive processes from both formal and informal networks and through interaction of governmental and nongovernmental entities (e.g., Pelling et al. 2008). Thus, the key aspects of the various definitional approaches that we focus on are that adaptive governance (1) is capable of self-organizing through formal and informal networks at the scale and in response to change; (2) facilitates an ability to learn; and (3) has the capacity to evolve. We adopt this broad view in the AWG Project and rather than choose a specific definition, rely in particular on the following literature to paint a picture of the concept of adaptive governance.

Dietz et al. (2003) introduced the term adaptive governance in recognizing self-organization as an alternative path to governing the commons in contrast to Hardin's (1968) focus on property rights and government regulation as the only options. Unpacking their conceptual figure of general principles leads to the following list of governance principles and it is important to note that the list is almost entirely composed of actions that may be facilitated by law: congruence of rules with ecological conditions; analytical deliberation/participation; clear boundaries and defined rights; enforced sanctions; mechanisms for dispute resolution; institutional variety; accountability; analytical deliberation/ participation; and nesting (Fig. 3 in Dietz et al. 2003).

Folke et al. (2005) stressed the need for adaptive governance with focus on the social aspects of governance as a means to gain acceptance of adaptive management and to assure the organizational learning and ability to navigate competing values and interests that is necessary for its implementation. The authors include the following in their criteria: social capital including trust, common rules, leadership, and experience; networks and bridging organizations within a polycentric governance structure; and a devolution of management rights and power sharing that promotes participation. Huitema et al. (2009) synthesize the views on adaptive governance and attempt a list of components needed in the water governance context: polycentricity, public participation, experimentation, and a bioregional perspective. Although we rely on this work, we go beyond those who would define adaptive governance as simply the means to implement adaptive management. We are influenced by the work of Craig and Ruhl (2014) who propose that adaptive management is appropriate when goals are set, uncertainty is high, and the ability to control experimentation is also high. In most instances, the management of major river basins is characterized by competing interests, jurisdictional complexity, and multiple drivers of change, and thus the ability to identify single management goals and to control experimentation is limited. In these more complex cases, adaptive governance is needed to assure accountability in goal setting and experimentation and adaptive management may be only one of many tools relied on for management in the face of uncertainty.
The importance of this distinction is captured in the work of Lebel et al. (2006) who describe the type of governance needed to manage resilience in social-ecological systems. Their attention not only to the adaptive aspects of governance, but to what is required for society to adopt a particular approach to governance, come closest to capturing an understanding of adaptive governance that bridges law and resilience. Thus, Lebel et al. (2006) view adaptive governance as requiring (1) certain attributes of good governance, i.e., participation and deliberation in process, polycentric and multilayered institutions, and accountable and just authority; and (2) capacity to manage resilience, i.e., ability to function at multiple scales and across scales, ability to anticipate and cope with uncertainty, ability to design institutions to fit social and ecological contexts, ability to detect and navigate thresholds, ability to integrate different forms of knowledge, and the ability to maintain ecological and social diversity. Although admitting that their findings are "tentative," the authors find evidence to link the attributes of good governance to the capacity to manage resilience in several case studies, documenting that,

(1) participation builds the trust, and deliberation the shared understanding, needed to mobilize and selforganize; (2) polycentric and multilayered institutions improve the fit between knowledge, action, and socioecological contexts in ways that allow societies to respond more adaptively at appropriate levels; and (3) accountable authorities who also pursue just distributions of benefits and involuntary risks enhance the adaptive capacity of vulnerable groups and society as a whole (Lebel et al. 2006).

In the broader governance literature, the move to distributed, collaborative governance is referred to as "new governance" (Lee 2003, Karkkainen 2004, Lockwood et al. 2010), with many similarities to adaptive governance and thus useful to our understanding of the concept. Lockwood et al. (2010) discuss this move to new governance as a product of the rise of informal, nongovernmental aspects of governance because of the increase in interdependency and interaction and the pressure for a greater citizen voice in natural resources management (Lockwood et al. 2010). Similar to adaptive governance, Lockwood et al. (2010) characterize new governance as capable of addressing problems "characterized by complexity, uncertainty, interdependency, and deficiencies in resources, expertise, and knowledge" (Lockwood et al. 2010).

In each of these foundational articles we see not a narrowly constructed list of criteria that must be present to label the approach adaptive governance, but a quest to identify those aspects of governance that seem most likely to lead to emergence and acceptance of adaptive processes and solutions. The focus is on means to facilitate social learning when governing common natural resources in the face of uncertainty (Pahl-Wostl et al. 2007), and the capacity for environmental governance to evolve.

It is also important to note that adaptive governance is not a panacea for natural resource management. Bridging the concepts of resilience and adaptive governance leads us to the conclusion that adaptive governance is appropriate when the system is complex, e.g., lies within multiple jurisdictions; the system faces change with a high degree of uncertainty, e.g., climate and other 
types of environmental change; and the system is approaching a potential threshold or regime shift as evidenced by increasing conflict over resources, increasing scarcity, or actual identification of an approaching threshold. e.g., listing of species, exceeding water quality standards, or insufficient water for basic needs. In addition, as will be apparent in the articles in this special feature, the specific approach to adaptive governance must be tailored to the contextual setting in which it is employed.

\section{SPECIAL FEATURE: PRACTICAL PANARCHY: INTEGRATING LAW, RESILIENCE, AND ADAPTIVE GOVERNANCE}

The articles in this special feature explore three themes emerging from our study of the social-ecological systems of complex water basins using the case studies in the Anacostia River, Columbia River, Klamath River, Middle Rio Grande River, Platte River, and Everglades wetland. First, resilience assessment of a variety of water basins revealed important aspects of the adaptive capacity of complex social-ecological systems as well as similarities in drivers of change. Second, the articles contribute to the growing literature on adaptive governance by using the case studies not only to identify its emergence, but to identify potential, and specifically the characteristics that lead to that emergence. Third, the focus in each basin study on the role law plays in both facilitating and presenting barriers to adaptation provided considerable insight on how to set the stage for adaptive governance within a highly regulated federal system. A brief summary of each theme in relation to the specific articles follows.

\section{Social-ecological resilience of regional scale water systems}

Assessment of the resilience and adaptive capacity of water-based social-ecological systems was a theme emerging in three of the contributions to this special feature. The first, by Gunderson et al. (2017) explores the three trajectories of systems subjected to change and suggests that different aspects of adaptive capacity appear in each trajectory in the water basin systems. During phases of development and stabilization, adaptive capacity of the system was determined by infrastructure that was designed and constructed within specific biophysical limits. That is, these systems were designed and built to control extremes of hydrological input (floods and droughts) up to specific design limits based on historic patterns of precipitation and flow. In this sense, the adaptive capacity of the system was defined and thus limited by the physical infrastructure and operating rules. When the limits of the biophysical system were exceeded leading to periods of crisis and recovery another form of adaptive capacity was revealed that entailed new structures and rules that as managers and those dependent on the infrastructure learned about the limits of the extant system. All of the systems underwent regime shift when sudden and unforeseen social or biophysical triggers led to new structures, institutions, laws and social agreements. Cross scale interactions among levels and sectors of government and society played both positive and negative roles in adaptive capacity. The basin studies illustrated that they may constrain development trajectories, but may also provide stability during crisis or innovation at smaller scales; trigger crises, but may also facilitate recovery; and constrain system transformation, but may also provide windows of opportunity in which transformation may occur and provide the resources to accomplish these transformations.
One of the foremost challenges to intentional facilitation of adaptation or transformation is the inability to quickly access system resilience and to manage uncertainty in that assessment. Allen et al. (2018) explore techniques to rapidly assess socialecological resilience using an online survey instrument and data/ information from that survey to more explicitly understand tradeoffs and uncertainty measures in resilience assessments. The authors received information from stakeholder groups including representatives of government, end users, agency/public science sector and nongovernmental groups (NGOs) for four of the six case study basins. Rather than seek an absolute measure of resilience (Allen et al. 2016), the authors focused on relative resilience across the watershed systems, and found that stakeholder response revealed trade-offs among different sector groups with respect to social, economic, and ecologic components. They propose that types of uncertainty and subjectivity of perceptions can reveal mental models that contribute to adaptive capacity of the system.

Arnold et al. (2017) employ a process of coding and analyzing secondary texts from the case studies to reveal four general drivers of change: (1) societal commodification of nature, (2) population growth and development of land, water, and technology, (3) sociopolitical exercise of power and the resulting inequalities, and (4) the dynamics of social interactions as they play out in conflict and collaboration, trust and distrust, and the norms surrounding cultural/spiritual beliefs and practices.

\section{Adaptive environmental governance}

A key theme of this special feature is the definition and description and emergence of adaptive environmental governance. Cosens et al. (2017) define governance as both governmental and nongovernmental participation in collective choice and action. The authors illustrate that the focus of current literature on the emergent aspects of adaptive governance misses the intersecting, intentional role of government and that this gap is a major factor in the failure of adaptive management and governance in the case studies. Cosens and colleagues (2017) suggest that adaptive environmental governance will require flexibility and action that is currently absent in heavily administrative governments in many Western democracies. The authors use the case studies to illustrate that attention to three aspects of governmental legal authority is essential to removing barriers and increasing governmental facilitation of adaptation and transformation: (1) structure, including polycentric jurisdictional authority and level at which decisions are made; (2) adaptive and facilitation of participatory capacity in the implementation of environmental regulation and management; and (3) the process of agency action to increase the likelihood of acceptance of more flexible implementation through attention to legitimacy and accountability.

Craig et al. (2017) add that in addition, adaptive governance must work on the ground, through legitimate and fair processes needed for adaptation to global environmental change. The authors explore the tension between the expectation of stability and the need for flexibility to implement adaptive governance.

DeCaro et al. (2017a) acknowledge that global environmental change, including climate change, is forcing environmental governance systems to become more adaptive. They argue that for environmental governance to be adaptive it should (1) encourage collaborative problem solving, (2) garner social 
acceptance and commitment, and (3) cultivate trust and tolerance for change and uncertainty. In order to meet these conditions, governance should be perceived as legitimate, trustworthy, and acceptable, while satisfying people's needs for self-determination, fairness, and security. DeCaro and colleagues (2017b) also present institutional and legal foundations for adaptive governance. Their framework describes the legal underpinnings for multidimensional, polycentric, self-organized, and emergent structures that pursue innovation, social learning, and political deliberation. They (DeCaro et al. 2017b) also argue that such frameworks are difficult in extant, top-down centers of authority, but are possible using existing tools to legitimize and facilitate self-organized coordination and collaboration across scales.

\section{Role of law in adaptation}

Another key finding of the project has been that law determines the role of government in adaptive governance and can be a double-edged sword in that it can provide both barriers and bridges to adaptive environmental governance. Cosens et al. 2017 explore the role of law to illustrate that (1) law determines the structure of government and thus the level at which decisions are made and thus the opportunity for innovation and contextualization; (2) substantive laws determine the capacity of government to adapt agency action; (3) law may influence the capacity of various interests to participate particularly when it alters the distribution of power among stakeholders, resource users, and other interests; and (4) administrative law governing the process of government may be used to ensure legitimacy and thus increase public acceptance of flexible management in the face of uncertainty.

Craig and colleagues (2017) specifically explore one of the greatest challenges of governmental facilitation of adaptive governance: the need to balance flexibility and stability. They conclude that attention to process and procedure (including participation), as well as increased use of substantive standards (instead of rules dictating how to achieve those standards), may allow an increased level of substantive flexibility to operate with legitimacy and fairness, providing the requisite levels of psychological, social, and economic stability needed for communities to successfully adapt.

Gosnell et al. (2017) argue that applications of regulatory law such as the Endangered Species Act can open a window of opportunity that leads to the emergence of adaptive processes. This can occur through collaborative processes that are needed to overcome piecemeal compliance and seek comprehensive solutions.

We invite the reader to pursue the arguments presented in the articles of the special feature, with an eye toward lessons from these highly developed water management systems that paradoxically are perhaps the most technologically advanced yet least resilient social-ecological systems in the face of changing conditions. We hope that the articles spur discussion and discourse to increase our collective adaptive capacity as we face the challenges of global environmental change.

\section{Responses to this article can be read online at:} http://www.ecologyandsociety.org/issues/responses. $\mathrm{php} / 9524$

\section{Acknowledgments:}

This work was developed under the Adaptive Water Governance Project, funded by the U.S. National Socio-Environmental Synthesis Center (SESYNC) under funding from the U.S. National Science Foundation, NSF DBI-1052875. The authors would like to thank Margaret Palmer and Jonathan Kramer of SES YNCfor their belief in and support of this project. We would also like to thank the members of the Adaptive Water Governance Team whose work is reflected in the articles in this special issue, and without whom, this endeavor would not have been possible.

\section{LITERATURE CITED}

Allen, C. R., D. G. Angeler, G. S. Cumming, C. Folke, D. Twidwell, and D. R. Uden. 2016. Quantifying spatial resilience. Journal of Applied Ecology 53:625-635. http://dx.doi.org/10.1111/1365-2664.12634

Allen, C. R., H. Birge, D. G. Angeler, C. A. (T.) Arnold, B. C. Chaffin, D. A. DeCaro, A. S. Garmestani, and L. Gunderson. 2018. Quantifying uncertainty and trade-offs in resilience assessments. Ecology and Society 23(1):03. https://doi. org/10.5751/ES-09920-230103

Arnold, C. A. (T.), H. Gosnell, M. H. Benson, and R. K. Craig. 2017. Cross-interdisciplinary insights into adaptive governance and resilience. Ecology and Society 22(4):14. http://dx.doi. org/10.5751/ES-09734-220414

Arnold, C. A. (T.), O. O. Green, D. DeCaro, A. Chase, and J. G. Ewa. 2014. The social-ecological resilience of an eastern urbansuburban watershed: the Anacostia River Basin. Idaho Law Review 51:30-90.

Benson, M. H., D. Llewellyn, R. Morrison, and M. Stone. 2014. Water governance challenges in New Mexico's Middle Rio Grande Valley: a resilience assessment. Idaho Law Review 51:195-228. http://dx.doi.org/10.2139/ssrn.2464387

Berkes, F., J. Colding, and C. Folke. 2002. Navigating socialecological systems: building resilience for complexity and change. Cambridge University Press, Cambridge, UK. http://dx.doi. org/10.1017/CBO9780511541957

Birge, H. E., C. R. Allen, R. K. Craig, A. S. Garmestani, J. A. Hamm, C. Babbitt, K. Nemec, and E. Schlager. 2014. Socialecological resilience and law in the Platte River Basin. Idaho Law Review 51: 229-256.

Brunner, R. D., T. A. Steelman, L. Coe-Juell, C. M. Cromley, C. M. Edwards, and D. W. Tucker. 2005. Adaptive governance: integrating science, policy, and decision making. Columbia University Press, New York, New York, USA.

Brundtland Commission. 1987. Report of the World Commission on Environment and Development: Our common future. Oxford University Press, Oxford, UK. [online] URL: http://www.undocuments.net/our-common-future.pdf

Chaffin, B. C., R. K. Craig, and H. Gosnell. 2014a. Resilience, adaptation, and transformation in the Klamath River Basin social-ecological system. Idaho Law Review 51:157-193.

Chaffin, B. C., A. S. Garmestani, L. H. Gunderson, M. H. Benson, D. G. Angeler, C. A. (T.) Arnold, B. Cosens, R. K. Craig, J. B. 
Ruhl, and C. R. Allen. 2016. Transformative environmental governance. Annual Review of Environment and Resources 41:399-423. http://dx.doi.org/10.1146/annurev-environ-110615-085817

Chaffin, B. C., H. Gosnell, and B. A. Cosens. 2014b. A decade of adaptive governance scholarship: synthesis and future directions. Ecology and Society 19(3):56. http://dx.doi.org/10.5751/ ES-06824-190356

Chaffin, B. C., and L. H. Gunderson. 2016. Emergence, institutionalization and renewal: rhythms of adaptive governance in complex social-ecological systems. Journal of Environmental Management 165:81-87. http://dx.doi.org/10.1016/j.jenvman.2015.09.003

Cosens, B. 2015. Application of the adaptive water governance project to the management of the Lake Eyre Basin and its connections to the Great Artesian Basin. Goyder Institute for Water Research, Adelaide, Australia. [online] URL: http://www. goyderinstitute.org/r89/media/system/attrib/file/80/FU\%20LEB $\%$ 20GAP $\% 20$ Report-WEB.pdf

Cosens, B. 2016. Water law reform in the face of climate change: learning from drought in Australia and the western United States. In C. Holley and D. Sinclair, editors. Special Issue: "Rethinking Water Law and Governance." Environmental and Planning Law Journal 33 .

Cosens, B. A., R. K. Craig, S. Hirsch, C. A. (T.) Arnold, M. H. Benson, D. A. DeCaro, A. S. Garmestani, H. Gosnell, J. Ruhl, and E. Schlager. 2017. The role of law in adaptive governance. Ecology and Society 22(1):30. http://dx.doi.org/10.5751/ ES-08731-220130

Cosens, B., and A. Fremier. 2014. Assessing system resilience and ecosystem services in large river basins: a case study of the Columbia River Basin. Idaho Law Review 51:91-125.

Cosens, B., L. Gunderson, and B. Chaffin. 2014. The adaptive water governance project: assessing law, resilience and governance in regional socio-ecological water systems facing a changing climate. Idaho Law Review 51:1-27.

Craig, R. K., A. S. Garmestani, C. R. Allen, C. A. Arnold, H. Birgé, D. A. DeCaro, A. K. Fremier, H. Gosnell, and E. Schlager. 2017. Balancing stability and flexibility in adaptive governance: an analysis of tools available in U.S. environmental law. Ecology and Society 22(2):3. https://doi.org/10.5751/ES-08983-220203

Craig, R. K., and J. B. Ruhl. 2014. Designing administrative law for adaptive management. Vanderbilt Law Review 67:1. http://dx. doi.org/10.2139/ssrn.2222009

DeCaro, D. A., C. A. (T.) Arnold, E. F. Boamah, and A. S. Garmestani. 2017a. Understanding and applying principles of social cognition and decision making in adaptive environmental governance. Ecology and Society 22(1):33. https://doi. org/10.5751/ES-09154-220133

DeCaro, D. A., B. C. Chaffin, E. Schlager, A. S. Garmestani, and J. B. Ruhl. 2017b. Legal and institutional foundations of adaptive environmental governance. Ecology and Society 22(1):32. https:// doi.org/10.5751/ES-09036-220132

Delmas, M. A., and O. R. Young, editors. 2009. Governance for the environment: new perspectives. Cambridge University Press, Cambridge, UK. http://dx.doi.org/10.1017/CBO9780511627170
Dietz, T., E. Ostrom, and P. C. Stern. 2003. The struggle to govern the commons. Science 302:1907-1912. http://dx.doi.org/10.1126/ science. 1091015

Folke, C., T. Hahn, P. Olsson, and J. Norberg. 2005. Adaptive governance of social-ecological systems. Annual Review of Environment and Resources. 30:441-473. http://dx.doi.org/10.1146/ annurev.energy.30.050504.144511

Gosnell, H., B. C. Chaffin, J. Ruhl, C. A. (T.) Arnold, R. K. Craig, M. H. Benson, and A. Devenish. 2017. Transforming (perceived) rigidity in environmental law through adaptive governance: a case of Endangered Species Act implementation. Ecology and Society XX(YY):ZZ. http://dx.doi.org/10.5751/ES-09887-XXYYZZ

Green, O. O., A. S. Garmestani, C. R. Allen, L. H. Gunderson, J. B. Ruhl, C. A. Arnold, N. A. J. Graham, B. Cosens, D. G. Angeler, B. C. Chaffin, and C. S. Holling. 2015. Barriers and bridges to the integration of social-ecological resilience and law. Frontiers in Ecology and the Environment 13(6):332-337. http://dx. doi.org/10.1890/140294

Gunderson, L., B. A. Cosens, B. C. Chaffin, C. A. (T.) Arnold, A. K. Fremier, A. S. Garmestani, R. K. Craig, H. Gosnell, H. E. Birge, C. R. Allen, M. H. Benson, R. R. Morrison, M. C. Stone, J. A. Hamm, K. Nemec, E. Schlager, and D. Llewellyn. 2017. Regime shifts and panarchies in regional scale social-ecological water systems. Ecology and Society 22(1):31. http://dx.doi. org/10.5751/ES-08879-220131

Gunderson, L., A. Garmestani, K. W. Rizzardi, J. B. Ruhl, and A. Light. 2014. Escaping a rigidity trap: governance and adaptive capacity to climate change in the Everglades social ecological system. Idaho Law Review 51:127-156.

Gunderson, L. H., and C. S. Holling editors. 2002. Panarchy: understanding transformations in human and natural systems. Island Press, Washington, D.C., USA.

Gunderson, L., C. S. Holling, and S. S. Light. 1995. Barriers and bridges to the renewal of ecosystems and institutions. Columbia University Press, New York, New York, USA.

Gunderson, L. H., and S. S. Light. 2006. Adaptive management and adaptive governance in the Everglades ecosystem. Policy Sciences 39:323-334. http://dx.doi.org/10.1007/s11077-006-9027-2

Gunderson, L. H. and L. Pritchard. 2002. Resilience and the behavior of large scale systems, Island Press, Washington, D.C., USA.

Hardin, G. 1968. The tragedy of the commons. Science 162:1243-1248. http://dx.doi.org/10.1126/science.162.3859.1243

Holling, C. S. 1973. Resilience and stability of ecological systems. Annual Review of Ecology and Systematics 4:1-23. http://dx.doi. org/10.1146/annurev.es.04.110173.000245

Holling, C. S. 1978. Adaptive environmental assessment and management. Wiley and Sons, London, UK.

Holling, C. S., and L. H. Gunderson. 2002. Resilience and adaptive cycles. Pages 25-62 in L. H. Gunderson and C. S. Holling, editors. Panarchy: understanding transformations in human and natural systems. Island Press, Washington, D.C., USA. 
Hughes, T. P., L. H. Gunderson, C. Folke, A. H. Baird, D. Bellwood, F. Berkes, B. Crona, A. Helfgott, H. Leslie, J. Norberg, M. Nyström, P. Olsson, H. Österblom, M. Scheffer, H. Schuttenberg, R. S. Steneck, M. Tengö, M. Troell, B. Walker, J. Wilson, and B. Worm. 2007. Adaptive management of the Great Barrier Reef and the Grand Canyon world heritage areas. Ambio 36:586-592. http://dx.doi.org/10.1579/0044-7447(2007)36[586:AMOTGB] 2.0. $\mathrm{CO} ; 2$

Huitema, D., E. Mostert, W. Egas, S. Moellenkamp, C. PahlWostl, and R. Yalcin. 2009. Adaptive water governance: assessing the institutional prescriptions of adaptive (co-)management from a governance perspective and defining a research agenda. Ecology and Society 14(1):26. http://dx.doi.org/10.5751/ES-02827-140126

Karkkainen, B. C. 2004. "New governance" in legal thought and in the world: some splitting as antidote to overzealous lumping. Minnesota Law Review 89:471-497.

Lebel, L., J. M. Anderies, B. Campbell, C. Folke, S. HatfieldDodds, T. P. Hughes, and J. Wilson. 2006. Governance and the capacity to manage resilience in regional social-ecological systems. Ecology and Society 11(1):19. http://dx.doi.org/10.5751/ ES-01606-110119

Lee, K. N. 1993. Compass and gyroscope. Island Press, Washington, D.C., USA.

Lee, M. 2003. Conceptualizing the new governance: a new institution of social coordination. Presented at the Institutional Analysis and Development Mini-Conference, May 3-5, Workshop in Political Theory and Policy Analysis. Indiana University, Bloomington, Indiana, USA. [online] URL: https:// pdfs.semanticscholar.org/71ec/0b861a6dad2d93b56ab5f8c6b77bfa415a48. pdf

Lemos, M. C., and A. Agrawal. 2006. Environmental governance. Annual Review of Environment and Resources 31:297-325. http:// dx.doi.org/10.1146/annurev.energy.31.042605.135621

Lockwood, M., J. Davidson, A. Curtis, E. Stratford, and R. Griffith. 2010. Governance principles for natural resource management. Society \& Natural Resources 23(10):986-1001. http://dx.doi.org/10.1080/08941920802178214

LoSchiavo, A. J., R. G. Best, R. E. Burns, S. Gray, M. C. Harwell, E. B. Hines, A. R. McLean, T. St. Clair, S. Traxler, and J. W. Vearil. 2013. Lessons learned from the first decade of adaptive management in comprehensive Everglades restoration. Ecology and Society 18(4):70. http://dx.doi.org/10.5751/ES-06065-180470

Lyon, T. P. 2009. Environmental governance: an economic perspective. Pages 43-68 in M. A. Delmas and O. R. Young, editors. Governance for the environment: new perspectives. Cambridge University Press, Cambridge, UK. http://dx.doi. org/10.1017/CBO9780511627170.004

McGinnis, M. D., and E. Ostrom. 2014. Social-ecological system framework: initial changes and continuing challenges. Ecology and Society 19(2):30. http://dx.doi.org/10.5751/ES-06387-190230

Ostrom, E. 1990. Governing the commons: the evolution of institutions for collective action. Cambridge University Press, Cambridge, UK. http://dx.doi.org/10.1017/CBO9780511807763
Ostrom, E. 2009. A general framework for analyzing sustainability of social-ecological systems. Science 325:419-422. http://dx.doi.org/10.1126/science.1172133

Pahl-Wostl, C., J. Sendzimir, P. Jeffrey, J. Aerts, G. Berkamp, and K. Cross. 2007. Managing change toward adaptive water management through social learning. Ecology and Society 12 (2):30. http://dx.doi.org/10.5751/ES-02147-120230

Pelling, M., C. High, J. Dearing, and D. Smith. 2008. Shadow spaces for social learning: a relational understanding of adaptive capacity to climate change within organisations. Environment and Planning A 40(4):867-884. http://dx.doi.org/10.1068/a39148

Repko, A. F. 2011. Interdisciplinary research: process and theory. Second edition. Sage, New York, New York, USA.

Rogers, P., and A. W. Hall. 2003. Effective water governance. Global Water Partnership Technical Committee (TEC) Background Paper 7. Global Water Partnership, Stockholm, Sweden. [online] URL: http://www.gwp.org/Global/ToolBox/ Publications/Background $\% 20$ papers/07\%20Effective $\% 20$ Water $\%$ 20Governance $\% 20 \% 282003 \% 29 \% 20$ English.pdf

Schultz, L., C. Folke, H. Österblom, and P. Olsson. 2015. Adaptive governance, ecosystem management, and natural capital. Proceedings of the National Academy of Sciences 112 (24):7369-7374. http://dx.doi.org/10.1073/pnas. 1406493112

U.N. System Task Team. 2012. U.N. System Task Team on the post-2015 UN development agenda: governance and development. U.N. Development Programme, New York, New York, USA. [online] URL: http://www.un.org/millenniumgoals/pdf/Think $\%$ 20Pieces/7 governance.pdf

Walker, B., C. S. Holling, S. R. Carpenter, and A. Kinzig. 2004. Resilience, adaptability and transformability in social-ecological systems. Ecology and Society 9(2):5. http://dx.doi.org/10.5751/ ES-00650-090205

Walker, B., and D. Salt. 2006. Resilience thinking: sustaining ecosystems and people in a changing world. Island Press, Washington, D.C., USA.

Walters, C. J. 1986. Adaptive management of renewable resources. McGraw Hill, New York, New York, USA. 